\title{
Endoparasites of donkeys (Equus asinus) used in commercial skin exploitation in the Northeast of Brazil
}

\section{Endoparasitos de jumentos (Equus asinus) utilizados em uma exploração comercial de peles no Nordeste brasileiro}

\author{
Jamisson Bispo de Sousa Santos ${ }^{1}$ (D); Aline Rocha Silva ${ }^{2}$ (D); Jarbiane Gomes de Oliveira ${ }^{3}$ (D); \\ Ivana Ferro Carmo ${ }^{3}$ (D); Lucas Santana da Fonseca ${ }^{3}$ (D); Geyanna Dolores Lopes Nunes ${ }^{4}$ (D); \\ Chiara Albano de Araujo Oliveira ${ }^{2}$ (D); Pierre Barnabé Escodro ${ }^{3}$ \\ ${ }^{1}$ Universidade Federal de Sergipe, Campus Lagarto, Lagarto - SE, Brazil \\ ${ }^{2}$ Universidade Federal da Bahia, Escola de Medicina Veterinária e Zootecnia, Salvador - BA, Brazil \\ ${ }^{3}$ Universidade Federal de Alagoas, Centro de Engenharias e Ciências Agrárias, Rio Largo - AL, Brazil \\ ${ }^{4}$ Universidade Federal de Sergipe, Campus Sertão, Nossa Senhora da Glória - SE, Brazil
}

\begin{abstract}
The present study identified the main endoparasites present in donkeys (Equus asinus) used in skin exploitation located in Cando municipality, Bahia State, Northeast of Brazil. The samples were collected from September 2019. Feces were collected from the rectal ampulla of 34 animals, macroscopically visualized for parasitic forms, and microscopically evaluated to identify endoparasites forms using the McMaster method. Parasitological results were associated with sex, age, and bodyweight Stata Corp LLC 14. Endoparasites were found in $82.3 \%$ of the animals, with the egg count ranging from 50 to 1050 eggs per gram (EPG). The sole presence of superfamily Trichostronglylidae was observed in $67.6 \%$ of the donkeys, in 8.8\% co-infected by Trichostronglylidae and Eimeria spp., while Trichostronglylidae and Strongyloides westeri was detected in 2.9\%, and simultaneous infection by Trichostronglylidae, Strongyloides westeri, and Oxyuris equi was observed in $2.9 \%$. The occurrence of parasitic infections varies according to nutritional status, age, sex, and environmental exposure ( $\mathrm{p}>0.05$ ). A high occurrence of infection was observed in young animals and those with lower body weight.
\end{abstract} Keywords: Ejiao. Endoparasitism. Equidae. Mistreatment.

\section{RESUMO}

O presente trabalho identificou os principais endoparasitas em jumentos utilizados em uma exploração de pele localizada no município de Canudos, Estado da Bahia, Nordeste do Brasil. As amostras foram colhidas no período de setembro de 2019. Fezes de 34 jumentos, colhidas diretamente da ampola retal, foram visualizadas macroscopicamente para formas parasitárias e avaliadas microscopicamente para identificar endoparasitos pela técnica de McMaster. Os resultados parasitológicos foram associados com sexo, idade e peso corporal pelo Stata Corp LLC 14. Endoparasitas foram encontrados em $82,3 \%$ dos animais, com contagem de ovos variando de 50 a 1050 ovos por grama (OPG). Presença de unicamente parasitos da superfamília Trichostronglylidae foi observada em 67,6\% dos jumentos, 8,8\% estavam coinfectados por Trichostronglylidae e Eimeria spp., 2,9\% por Trichostronglylidae e Strongyloides westeri e 2,9\% apresentaram presença simultânea de Trichostronglylidae, Strongyloides westeri e Oxyuris equi. A ocorrência de infecções parasitárias varia de acordo com a idade, sexo e exposição ambiental ( $p>0.05$ ). Observou-se alta ocorrência de animais infectados nos animais jovens e naqueles com menor peso corporal.

Palavras-chave: Ejiao. Endoparasitismo. Equídeos. Maus-tratos. 


\section{Correspondence to:}

Jamisson Bispo de Sousa Santos

Universidade Federal de Sergipe, Campus Lagarto

Av. Gov. Marcelo Déda, São José

CEP: 49400-000, Lagarto - SE, Brazil

e-mail: jamissonbispo73vet@hotmail.com

Received: June 30, 2020

Approved: December 22, 2020

How to cite: Santos JBS, Silva AR, Oliveira JG, Carmo IF, Fonseca LS, Nunes GDL, Oliveira CAA, Escodro PB. Endoparasites of donkeys (Equus asinus) used in commercial skin exploitation in the Northeast of Brazil. Braz J Vet Res Anim Sci. 2021;58(special issue):e171512. https://doi.org/10.11606/issn.1678-4456.bjvras.2021.171512

\section{Introduction}

The domestication of donkeys (Equus asinus) began 6,000 years ago in Turkey, and via the Silk Route of Egypt, progressed to Italy and China for their commercial potential (Yilmaz et al., 2012). The first donkeys arrived in Brazil in 1549, along with herds of cattle and horses, mainly for agriculture, animal traction, and mining (Lima et al., 2006).

According to the Brazilian Institute of Geography and Statistics (Instituto Brasileiro de Geografia e Estatística, 2012), the Brazilian troop currently consists of 822,255 donkeys, with $90 \%$ of this herd in the Northeast region. Northeastern donkey is a local breed of rustic animals, adapted to the Brazilian Northeast semiarid region, differing from the robust national breeds such as the Pêga and the Paulista donkeys, which have a greater lineage from Italy and Portugal (Almeida, 2009). The Northeastern donkeys have always been present in the economic, social, and cultural activities of the Northeast, but are gradually being replaced by technological advancements, thus reducing their activity in agricultural fields.

Concurrently, a broad and aggressive extractive action is initiated in the Chinese market to produce "ejiao," a product made from donkey hide/skin for Chinese medicine (Bittencourt, 2019; The Donkey Sanctuary, 2017). Hide import is legal in China, and the import policies were facilitated by reducing the $5 \%$ tax to $2 \%$ in 2019 . Between 2007 and 2017 , the population of donkeys fell by $28 \%$ in Brazil, $37 \%$ in Botswana-Africa, and 53\% in Kyrgyzstan-Middle East (Lasserre, 2019; Ryall, 2019). According to The Donkey Sanctuary (2017), animals in the extractive hide trade go through unsanitary conditions in slaughterhouses in Brazil and other countries. Despite their rusticity, donkeys are susceptible to varied infectious and non-infectious diseases, with parasitic infections being of great concern (Chitra et al., 2011). These infections can cause intermittent diarrhea, colic, anorexia, depression, and weight loss, culminating in morbidity and death (The Donkey Sanctuary, 2017). Most of the studies related to parasitic diseases in donkeys are carried out in Africa, Europe, and Asia, which show the presence of Strongylus spp., Strongyloides westeri, and Oxyuris equi (Gianfaldoni et al., 2020; Mulwa et al., 2020; Zhang et al., 2017). The objective of this study was to identify the main endoparasites from donkeys used in skin exploitation in the Northeast of Brazil.

\section{Materials and Methods}

The experiment was approved by the Animal Use Ethics Committee of the Federal University of Alagoas (CEUA -UFAL), under identification number 21/2019. All animals involved in the research were evaluated ethically and following the veterinary care standards.

The study included 34 donkeys that were rescued from the hide exploration trade and sent to a refuge farm under veterinary care in the municipality of Cando's, Bahia ( $09^{\circ} 53^{\prime} 48^{\prime \prime}$ South, 39 $01^{\prime} 35^{\prime \prime}$ West). On examination, when the samples were collected in September 2019, the whole troop was negative for equine infectious anemia and glanders tests.

The study included 29 males and five females, with a mean age of $5.9 \pm 8.2$ years ( minimum $=2.5$, maximum $=16$ years , and average body weight of $106.7 \pm 126.6 \mathrm{~kg}$ ( minimum $=70 \mathrm{~kg}$, maximum $=143 \mathrm{~kg}$ ). Their vital parameters were evaluated.

Fecal samples were collected directly from the rectum and macroscopically evaluated for consistency, color, odor, and for the presence of mucus, blood, and adult parasitic forms. Using the Wilson \& Gordon (1988) method, samples were characterized in symbols as normal, deformed, and diarrheal, with colorings ranging from moss green to yellow tones, and with a sui generis fetid odor. Also, perianal regions were evaluated for any physical injuries that could indicate the presence of Oxyuris equi parasites. All of the fecal samples were collected in September 2019, stored in 5\% formalin solution, and microscopically quantitatively examined using the McMaster method (Gordon \& Whitlock, 2019). Descriptive statistical analysis was performed on Microsoft Excel (2013). The differences between the frequencies of parasites and age, sex, and weight were tested using the odds ratios (Stata 14) and statistical significance was considered at $\mathrm{p}<0.05$. 


\section{Results}

Of the 34 donkeys, $82.3 \%$ (28/34) were infected by gastrointestinal parasites, with a predominance of the nematodes of the superfamily Trichostronglylidae (76.6\%, 23/34). Co-infection of Trichostronglylidae and Eimeria spp. was seen in $8.8 \%$ (3/34) donkeys, while $2.9 \%$ (1/34) were infected by Trichostronglylidae and Strongyloides westeri, and $2.9 \%(1 / 34)$ by Trichostronglylidae, Strongyloides westeri, and Oxyuris equi, simultaneously (Table 1).

The mean EPG was 279, with a median of 150 (minimum $=0$, maximum $=1050$ ). Based on $E P G$, the severity of the infection is characterized as low (50-200 EPG), moderate (201-500 EPG), and high (>501 EPG). Low, moderate, and high infection was seen in $57.1 \%(16 / 28)$, $17.9 \%(5 / 28)$, and $25 \%$ (7/28) of donkeys, respectively.

Table 2 shows the distribution of donkeys based on sex, age, and weight. Most donkeys were males, ranging in ages from four to six years old, and weighing between 101 and $120 \mathrm{~kg}$. No association was observed between the presence of parasites and the variables analyzed $(p>0.05)$.

\section{Discussion}

This study allowed us to analyze a group of donkeys that were used as part of Chinese exploitation of donkey skin. Despite the great social contribution by donkeys, the animals have not received the necessary attention from public research agencies, and academic research on them is scarce. The animals of the present study are in a chain of skin and meat exportation.

The occurrence of gastrointestinal parasites was $82.3 \%$, similar to $89 \%$ observed by Mulwa et al. (2020) in Kenya, indicating the little care that these animals receive before slaughter. The feces were mostly deformed, with moss green coloring and a sui generis smell, and without the presence of visible parasitic forms. Microscopically, the predominance of the eggs of superfamily Trichostronglylidae was observed along with co-infections of Strongyloides westeri and Eimeria spp., similar to reports by Carvalho et al. (2007) and Gianfaldoni et al. (2020), in Portugal and Italy, respectively. The study demonstrated a low occurrence of Oxyuris equi in the donkeys, which was also observed by Sousa (2018) in Minas Gerais, Brazil, and Mulwa et al. (2020) in Kenya. This low occurrence is attributed to the process of elimination of eggs, which occurs primarily in the perianal region, with little or no presence of eggs in the feces collected from the donkey's rectum (Yilmaz et al., 2012).

Similar to observed by Jarere et al. (2016), the age of the donkey presented an association with the presence of parasites. All young animals (up to 3 years of age) presented parasite infection; this can be justified by the reduced ability of young animals to develop immunity against gastrointestinal helminths. Increased incidence of parasites was noted in donkeys weighing less than $100 \mathrm{~kg}$ (90.9\%). However, there was no statistical difference in the occurrence of gastrointestinal parasites concerning age, sex,

Table 1 - Gastrointestinal (GI) parasites found in donkeys used in commercial skin and meat exploitation located in Bahia State, Brazilian Northeast. Samples collected in September 2019

\begin{tabular}{lcc}
\hline \multicolumn{1}{c}{ Parasites } & Number of Positive animals & Proportion of Positive animals \% \\
\hline Super. Trichostrongylidae & 23 & $67.6 \%$ \\
Trichostrongylidae and Eimeria spp. & 3 & $8.8 \%$ \\
Super. Trichostrongylidae and S. westeri & 1 & $2.9 \%$ \\
Super. Trichostrongylidae, Strongyloides westeri and Oxyuris equi. & 1 & $2.9 \%$ \\
\hline
\end{tabular}

Table 2 - Frequency of gastrointestinal (GI) parasites in donkeys used in commercial skin and meat exploitation located in Bahia State, Brazilian Northeast. Samples collected in September 2019

\begin{tabular}{ccccc}
\hline \multirow{2}{*}{ Category } & \multirow{2}{*}{ Number of animals examined } & \multicolumn{3}{c}{ Presence of GI parasites } \\
\cline { 3 - 5 } & & Positive (\%) & OR $^{* *}$ & p-valor \\
\hline Sex & 5 & 80.0 & - & - \\
Female & 29 & 82.7 & 1.200 & 0.881 \\
Male & & & & $\mathrm{NC}^{1}$ \\
Age & 6 & 100.0 & $\mathrm{NC}^{1}$ & 0.874 \\
$<3$ years & 18 & 83.3 & 1.153 & 0.235 \\
$>3$ to 6 years & 10 & 70.0 & 0.333 & \\
$>6$ to 16 years & 11 & & & 0.380 \\
Body Weight & 16 & 90.9 & 2.777 & 0.874 \\
$<100 \mathrm{~kg}$ & 7 & 81.3 & 0.866 & 0.403 \\
$>100-120 \mathrm{~kg}$ & & 71.4 & 0.434 & \\
$>120 \mathrm{~kg}$ & &
\end{tabular}

${ }^{* *} \mathrm{OR}=$ Odds Ratio. $\mathrm{NC}^{1}$ = not calculated because all animals in this variable had parasites. - it was not possible to analyze. 
and body condition as also observed by Alshaibani et al. (2019) and Mezgebu et al. (2013).

Weight loss and weakness are signs of parasitic infection by superfamily Trichostronglylidae, causing increased intestinal transit, and decreased deposition of proteins, calcium, and phosphorus, leading to severe wasting (Urquart et al., 1998). Weight loss and dermatitis due to allergic response are also caused by $S$. westeri, which reduces digestive absorption, leading to apathy (European Scientific Counsel Companion Animal Parasites, 2019; Thamsborg et al., 2017). Other common symptoms of parasitic infection in donkeys are hair coat opacity, piloerection, and hair loss that can be caused by Eimeria ssp. and Oxyuris equi infection (Bowman, 2010; Taylor et al., 2017). Those clinical signals were observed in more than 50 animals from the donkey group studied. These results indicate the necessity to improve sanitary management, of donkeys that come from subsistence agriculture.

\section{References}

Almeida LD. Diversidade genética de raças asininas criadas no Brasil, baseada na análise de locos microssatélites e DNA mitocondrial [thesis]. Brasília: Faculdade de Agronomia e Medicina Veterinária, Universidade de Brasília; 2009 [cited 2020 Apr 10]. Available from: https://repositorio.unb.br/ bitstream/10482/7043/1/2009_LeonardoDanieldeAlmeida.pdf.

Alshaibani I, Aldalali Z, Al-Shaibani I. Epidemiological study on gastrointestinal nematodes of Donkeys in Dhamar Governorate Yemen. Saudi J Med Pharm Sci. 2019;5(5):379-85.

Bittencourt M. Após proibição de abates, 200 jumentos são encontrados mortos na Bahia [Internet]. UOL Economia; 2019 Feb 6 [cited 2020 Apr 10]. Available from: https:// economia.uol.com.br/ noticias/redacao/2019/02/06/ apos-proibicao-abate-jumentos-encontrados-mortos-ba. htm? cmpid=co piaecola.

Bowman DG. Parasitologia veterinária. 9. ed. Rio de Janeiro: Elsevier; 2010.

Carvalho MM, Cernea GM, Cernea C, Cantos CA, Bernardes N, Rosário MA, Soares M, Fazendeiro JI. Gastrointestinal parasites and its control in stabled donkeys and mules. Rev Port Ciênc Vet [Internet]. 2007 [cited 2020 June 30];102(563564):225-31. Available from: https://pdfs.semanticscholar. org/30e5/fa8234af0ec551b428346d96038c0e6eaa94 .pdf.

Chitra R, Rajendran S, Prasanna D, Kirubakaran A. Influences of age on the prevalence of parasitic infections among

\section{Conclusion}

Infection by nematode and protozoa was observed in the donkeys destined for slaughter. Despite the higher EPG that was found in young animals and those with lower body weight, statistical significance was not observed. Recommendations for future studies with donkeys include using a great number of animals and also doing fecal culture, which allows the identification of the Trichostronglylidae parasites involved in the infection.

\section{Conflict of Interest}

The authors declare that there is no conflict of interest.

\section{Ethics Statement}

The research was approved by the Animal Use Ethics Committee of the Federal University of Alagoas (CEUA -UFAL) (protocol 21/2019).

donkeys in Erode district, Tamilnadu, India. Vet World. 2011;4(6):258-9. http://dx.doi.org/10.5455/vetworld.4.258.

European Scientific Counsel Companion Animal Parasites ESCCAP. Guideline 08 Second Edition [Internet]. United Kingdom: ESCCAP; 2019 [cited 2020 June 25]. Available from: https://www.esccap.org/guidelines/gl8/.

Gianfaldoni C, Barlozzari G, Mancini S, Domenico ED, Maestrini M, Perrucci S. Parasitological investigation in an organic dairy donkey farm. Large Anim Rev [Internet]. 2020 [cited 2020 June 30];26:25-30. Available from: https:// www.largeanimalreview.com/index.php/lar/arti cle/view/96.

Gordon H, Whitlock HV. A new technique for counting nematode eggs in sheep faeces. J Counc Sci Ind [Internet]. 2019 [cited 2020 June 30];12(1):50-2. Avalaible from: https://www.scienceopen.com/document?vid=f8746abeba81-4cd5-b637-f08621127d6f.

Instituto Brasileiro de Geografia e Estatística - IBGE. Sistema IBGE de Recuperação Automática (SINDRA) [Internet]. 2012 [cited 2020 Apr 10]. Available from: https://sidra. ibge. gov.br/Tabela/73.

Jarere MS, Jallailudeen RL, Amina MB, Yakaka W, Usman AT, Ibrahim W. Risk factors associated with the occurrence of gastrointestinal helminths among indigenous donkeys (Equus asinus) in Northeastern Nigeria. Scientifica. 2016;2016:3735210. PMid:27366344. 
Lasserre C. Chinese trade in hides has led to global donkey massacre. Science; 2019 Dec 12. Available from: http:// dx.doi.org/10.1126/science.aba5498.

Lima RAS, Shirota R, Barros GSC. Estudo do complexo do agronegócio cavalo. Piracicaba: ESALQ/USP; 2006.

Mezgebu T, Tafess K, Tamiru F. Prevalence of gastrointestinal parasites of horses and donkeys in and around Gondar Town, Ethiopia. Open J Vet Med. 2013;3(6):267-72. http:// dx.doi.org/10.4236/ojvm.2013.36043.

Mulwa N, Githigia S, Karanja D, Mbae C, Zeyhle E, Mulinge E, Magambo J, Ogolla K. Prevalence and intensity of gastrointestinal parasites in donkeys in selected abattoirs in Kenya. Scientifica. 2020;2020:5672140. http://dx.doi. org/10.1155/2020/5672140.

Ryall J. Chinese medicine ejiao has worlds donkeys' population crisis, according to British study [Internet]. South China Morning Post (SCMP). 2019 Nov 24 [cited 2020 Apr 10]. Available from: https://www.scmp.com/news/ asia/east-asia/article/3039011/chinese-medicine-ejiao-hasleft-worldsdonkey-population-crisis.

Sousa FC. Prevalência de helmintoses de asininos e muares em lagoa Dourada, Minas Gerais [dissertation]. São João del Rey: Universidade Federal de São João Del Rei; 2018.

Taylor MA, Coop RL, Wall RL. Veterinary parasitology. 4. ed. Rio de Janeiro: Guanabara Koogan; 2017.
Thamsborg SM, Ketzis J, Horii Y, Matthews JB. Strongyloides spp. infections of veterinary importance. Parasitology. 2017;144(3):274-84. http://dx.doi.org/10.1017/ S0031182016001116. PMid:27374886.

The Donkey Sanctuary. Sob a pele: o que é EJIAO? O produto que impulsiona a demanda global por peles de burro [Internet]. 2017 [cited 2020 Apr 10]. Available from: https://www.thedonkeysanctuary.org.uk/what-we-do/issues/ donkey-meat-skin-and-milk/what-is-ejiao.

Urquart GM, Armour J, Duncan AM, Jennings FW. Parasitologia veterinária. 2 ed. Rio de Janeiro: Guanabara Koogan; 1998.

Wilson J, Gordon B. Equine colic: interpreting the diagnostic tests. Vet Med. 1988;82(8):629-645.

Yilmaz OY, Saim B, Mehmet E. The Domesticated Donkey: I - species characteristics. Can J Appl Sci [Internet]. 2012 [cited 2020 June 30];4(2):339-53. Available from: https:// www.academia.edu/10190406/The_Domesticated_Donkey_I_ Species_Characte ristics.

Zhang XX, Zhang FK, Li FC, Hou JL, Zheng WB, Du SZ, Zhao $\mathrm{Q}$, Zhu XQ. The presence of Giardia intestinalis in donkeys, Equus asinus, in China. Parasit Vectors. 2017;10(1):3. http:// dx.doi.org/10.1186/s13071-016-1936-0. PMid:28049541.

Financial Support: None. 